\title{
Increment of Steel Tonnage for Reinforced Concrete School Building Considering Seismic Design
}

\author{
H A Roslan, M I Adiyanto, S A H S Mustapa, T A Majid, N S H Harith
}

\begin{abstract}
A series of Indonesian earthquakes, especially from Sumatra caused vibration on buildings in Peninsular Malaysia like Kuala Lumpur and Penang Island. In East Malaysia, Sabah state has been classified as a region with active local seismic fault. A moderate earthquake with $M_{w} 6.1$ was occurred in Ranau on $5^{\text {th }}$ June 2015 and caused damage on buildings either the structural or non-structural members. Hence, the implementation of seismic design on new buildings is important to ensure public safety. However, such action has its own pro and contra especially when dealing with cost. Therefore, current research work presents the influence of seismic design consideration on the increment of cost for steel reinforcement. For that purpose, a four storey reinforced concrete school building was generated and used as basic model for analysis, design, and taking off. Two level of seismicity representing by the reference peak ground acceleration, $\alpha_{g R}$ equal to $0.07 \mathrm{~g}$ and $0.10 \mathrm{~g}$ has been taken into account in the structural analysis and seismic design process. Besides, three soil type namely as soil type A, soil type $C$, and soil type $E$ also has been considered as variable parameter. Based on result, total steel tonnage in beams for models considering seismic design increases around $14 \%$ to $119 \%$ higher than the model without seismic design. For columns, the increment is around 13\% to $155 \%$. Generally, total cost of steel used as for concrete reinforcement of the whole structure increases around $13 \%$ to $131 \%$ depending on the level of seismicity and soil type.
\end{abstract}

Keywords : Cost estimation; Eurocode 8; Seismic design; Steel tonnage.

\section{INTRODUCTION}

Geographically, Malaysia is formed by two main land namely as Peninsular and East Malaysia. The Peninsular Malaysia is situated at the southern part of Asia continent. The East Malaysia is situated in Borneo Island. The East Malaysia consist of two large states namely as Sarawak and

Revised Manuscript Received on October 22, 2019.

* Correspondence Author

Hanis Athirah Roslan, Department of Civil Engineering, College of Engineering, Universiti Malaysia Pahang, Gambang, Malaysia. Email: hanisathirahroslan@gmail.com

Mohd Irwan Adiyanto*, Department of Civil Engineering, College of Engineering, Universiti Malaysia Pahang, Gambang, Malaysia. Email: mirwan@ump.edu.my

Syed Abdul Haris Syed Mustapa, Department of Quantity Surveying, Faculty of Architecture, Planning, and Surveying, Universiti Teknologi Mara, Seri Iskandar, Perak, Malaysia. Email: haris_mercy@yahoo.com

Taksiah A Majid, Disaster Research Nexus, School of Civil Engineering, Universiti Sains Malaysia, Nibong Tebal, Malaysia. Email: taksiah@usm.my

Noor Sheena Herayani Harith, Faculty of Engineering, Universiti Malaysia Sabah, Kota Kinabalu, Malaysia. Email: sheena@ums.edu.my
Sabah. Both West and East Malaysia is relatively far away from Pacific-Ring of Fire regions.

However, Malaysia is considered to have low seismicity profile [1] Peninsular Malaysia is exposed to the Sumatra Andaman earthquakes. Due to the $M_{w} 9.1$ Acheh earthquake in December 2004, the nation is undergoing the long-term inter-seismic deformation toward south-east direction [2]. Local earthquakes also reported in Peninsular Malaysia especially Janda Baik and Bukit Tinggi which are located around $50 \mathrm{~km}$ from Kuala Lumpur. The Bukit Tinggi fault line which triggered earthquakes in 2007-2009 is believed as a result from Paleo fault line reactivation [3]. In East Malaysia, a large number of increment of earthquake events has been detected based on updated records from 1884 to 2016 [4]. A moderate earthquake with $\mathrm{M}_{\mathrm{w}} 6.1$ was occurred in Ranau on $5^{\text {th }}$ June 2015. The event caused damage on buildings either the structural or non-structural members [5]-[7]. Based on detail investigation, the highest damage recorded on brickwall with X-mark crack due to shear failure [8]. Hence, the implementation of seismic design on new buildings is important to ensure public safety. Seismic design practice should be adopted especially in Sabah which is categorized as moderate seismic region in order to reduce the damage to buildings [9].

Positively, the 2015 Ranau earthquake is seen as one of strong reason to considering seismic design for construction industry in Malaysia [6]. However, such action has its own pro and contra especially when dealing with cost. The consideration of earthquake load in design will directly influencing the cost of material which should be adopted by construction industry [10]. Seismic design tends to cause increment in total steel reinforcement which will directly increase the cost. However, the cost for repair and maintenance in the future will be reduced by implementation of seismic design [11].

A few research works had been conducted to determine the influence of seismic design to the cost increment of construction's materials. As an example, seismic design had been conducted with ductility class low on two storey reinforced concrete (RC) office building [10]. Authors concluded that the amount of steel reinforcement increase when seismic design consideration is taken into account. Based on seismic design on five and ten storey residential building, researchers concluded that the quantity of steel

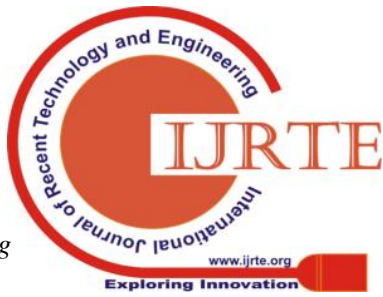


reinforcement had increased around $7 \%$ to $32.4 \%$ and $28 \%$ and $420.3 \%$ for beams and columns, respectively [11]. In other research work, it had been proven that the amount of steel reinforcement is highly affected by the value of reference peak ground acceleration, $\alpha_{\mathrm{gR}}$ as well as the ductility class [12]. The work had been conducted on a six storey hospital building.

This research works discusses the influence of seismic design on the increment of cost for steel reinforcement. A four storey RC school building was generated and used as basic model for analysis, design, and taking off. School buildings was selected because the building is important in housing hundreds to thousands young generation during school session. It also important to act as community shelter during disaster. Therefore, school buildings must survive during earthquake. Different level of seismicity and soil type had been considered as variable in this study. The result is presented in term of normalised total steel tonnage used as reinforcement.

\section{PROCEDURE FOR PAPER SUBMISSION}

In this study, a total of three stages had been conducted namely as generate basic model, followed by structural analysis \& seismic design, and then the taking off. Basic model generation took place in stage 1. As mentioned in previous section, a four storey RC school building was generated and used as basic model as presented by Fig. 1. The basic model has total height, $H$ up to $15.5 \mathrm{~m}$ where the fundamental period of vibration, $T_{1}$ is estimated to be equal to $0.60 \mathrm{sec}$. A total three sizes of beam has been considered which are equal to $300 \mathrm{~mm}$ x $600 \mathrm{~mm}, 200 \mathrm{~mm}$ x $450 \mathrm{~mm}$, and $200 \mathrm{~mm} \times 225 \mathrm{~mm}$ depend on the position and span. The columns has been modelled based on two sizes which is equal to $350 \mathrm{~mm}$ and $450 \mathrm{~mm}$ square.

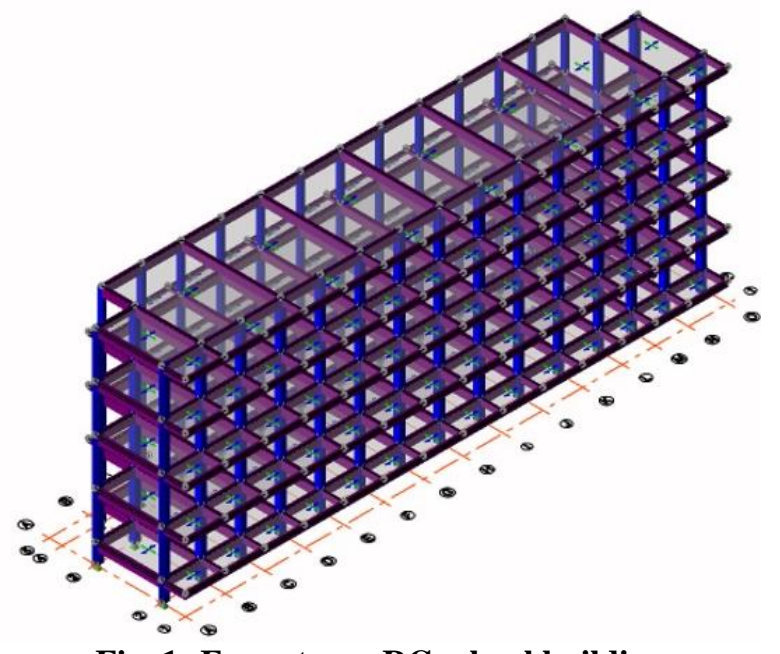

Fig. 1. Four storey RC school building

Stage 2 involving the structural analysis following by seismic design on the basic models. As recommended in [13], the basic models was classified in importance class III. Hence, 1.2 has been assigned as value for importance factor, $\gamma_{\mathrm{I}}$. Due to its importance after disaster, the recommended value of importance factor, $\gamma_{\mathrm{I}}=1.2$ in order to provide higher protection of life for such type of buildings [14]. RC school buildings always been converted to become a shelter for community after any disaster in Malaysia. Therefore, the RC school building must be stronger than any other ordinary buildings. The imposed load, $Q_{\mathrm{k}}$ was assigned on the basic model based on Category $\mathrm{C} 1$ as proposed in [15].

In this study, the level of seismicity and soil type has been considered as variable. The level of seismicity is represented by the value of reference peak ground acceleration, $\alpha_{\mathrm{gR}}$ indicates the intensity of earthquake in a specific region. Two level of seismicity has been considered which is equal to $0.07 \mathrm{~g}$ and $0.10 \mathrm{~g}$ to represent the seismicity in Lumut, and Semporna, respectively as in [16]. In addition, a total of three soil type has been considered namely as A, C, and E as proposed in [13]. In this study, seven models has been analysed and designed as shown in Table I. One model without seismic consideration has been taken into account for control and result normalisation purpose. All models were designed by considering concrete grade C30/37 and yield strength of steel, $f_{\mathrm{y}}=500 \mathrm{~N} / \mathrm{mm}^{2}$. Ductility class medium has been considered for models with seismic design. The structural analysis on models with seismic design was conducted by using lateral force method by referring to [13].

Table- I: Design parameters for rc school models

\begin{tabular}{|c|c|c|c|}
\hline No & Code & $\begin{array}{c}\text { Reference peak ground } \\
\text { acceleration, } \alpha_{g R}(g)\end{array}$ & Soil Type \\
\hline 1 & NS & - & - \\
\hline 2 & A-0.07 & 0.07 & A \\
\hline 3 & A-0.10 & 0.10 & A \\
\hline 4 & C-0.07 & 0.07 & C \\
\hline 5 & C-0.10 & 0.10 & C \\
\hline 6 & E-0.07 & 0.07 & E \\
\hline 7 & E-0.10 & 0.10 & E \\
\hline
\end{tabular}

\section{RESULT AND DISCUSSION}

\section{A. Earthquake Load on Models}

In this study, earthquake load, $E$ acting on all models with seismic design was calculated by using the lateral force method. This method derives the total earthquake load, $E$ which imposed laterally in form of base shear force, $F_{\mathrm{b}}$. The latter is then being distributed on every storey as explained by [17]. The magnitude of the dead load, $G_{\mathrm{k}}$ and the imposed load, $Q_{\mathrm{k}}$ were similar to all models. By referring to [13], the magnitude of base shear force, $F_{\mathrm{b}}$ is directly proportional to the value of spectral acceleration at the fundamental period of vibration, $S_{\mathrm{d}}\left(T_{1}\right)$, effective mass of the building, $m$ and correction factor, $\lambda$. The value of spectral acceleration at the fundamental period of vibration, $S_{\mathrm{d}}\left(T_{1}\right)$ for all models were obtained from on the design response spectrum which has been developed for every level of seismicity and soil type. Besides, the effective mass of the building, $m$ as well as the correction factor, $\lambda$ are similar and fix for all models.

The magnitude of base shear force, $F_{\mathrm{b}}$ is presented in Table II which shows the magnitude of base shear force, $F_{\mathrm{b}}$ are differ for every models. The results clearly show that the magnitude of base shear force, $F_{\mathrm{b}}$ increases as the level of

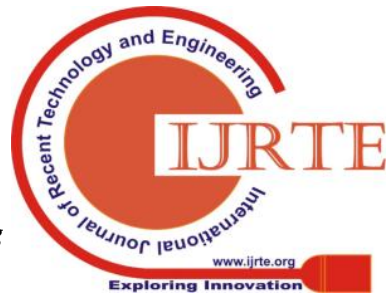


seismicity increases. It indicates that for similar soil type, a similar building tend to be imposed by different magnitude of lateral load depending on level of seismicity of a specific region. Results in Table 2 also show that once the level of seismicity is similar, the magnitude of base shear force, $F_{\mathrm{b}}$ will be differ for different soil type. As an example, for seismicity with reference peak ground acceleration, $\alpha_{\mathrm{gR}}=$ $0.10 \mathrm{~g}$ the magnitude of base shear force, $F_{\mathrm{b}}$ are equal to $1074.6 \mathrm{kN}, 1810.1 \mathrm{kN}$, and $1880.6 \mathrm{kN}$ for models considering soil type A, soil type C, and soil type E, respectively. This result is contributed by different soil factor, $S$ specified for every soil type as proposed by [13]. The seismicity on softer soil type tends to be amplified by higher factor which lead to severe damage compared to harder soil type. In Table II, the highest magnitude of base shear force, $F_{\mathrm{b}}$ is model E-0.10 which considering reference peak ground acceleration, $\alpha_{\mathrm{gR}}=$ $0.10 \mathrm{~g}$ and soil type $\mathrm{E}$. This means the model had been imposed to the highest magnitude of lateral force on every storey.

Table- II: Earthquake load, $E$ acting on all models

\begin{tabular}{|c|c|c|c|}
\hline No & $\begin{array}{l}\text { Model } \\
\text { Code }\end{array}$ & $\begin{array}{l}\text { Spectral acceleration at the } \\
\text { fundamental period of } \\
\text { vibration, } \boldsymbol{S}_{\boldsymbol{d}}\left(\boldsymbol{T}_{\boldsymbol{I}}\right)\left(\boldsymbol{m} / \mathbf{s}^{2}\right)\end{array}$ & $\begin{array}{c}\text { Base shear force, } \\
\boldsymbol{F}_{\boldsymbol{b}}(\boldsymbol{k N})\end{array}$ \\
\hline 1 & NS & Non applicable & Non applicable \\
\hline 2 & $\mathrm{~A}-0.07$ & 0.361 & 752.2 \\
\hline 3 & $\mathrm{~A}-0.10$ & 0.515 & 1074.6 \\
\hline 4 & $\mathrm{C}-0.07$ & 0.607 & 1267.1 \\
\hline 5 & $\mathrm{C}-0.10$ & 0.868 & 1810.1 \\
\hline 6 & $\mathrm{E}-0.07$ & 0.631 & 1316.4 \\
\hline 7 & $\mathrm{E}-0.10$ & 0.901 & 1880.6 \\
\hline
\end{tabular}

\section{B. Total Volume of Concrete}

In this study, the size of beams and columns are similar for all models regardless the design consideration. Therefore, the volume of concrete for beams and columns is similar for all models which is equal to $245 \mathrm{~m}^{3}$. Therefore, the cost for concrete is estimated to be similar for all models.

\section{Total Steel Tonnage}

The steel tonnage representing the total amount of steel bar used as the flexural and the shear reinforcement. The number and size of steel reinforcement strongly influenced by the magnitude of bending moment, $M$ shear force, $V$ and axial load, $P$ [12]. The steel tonnage in $1 \mathrm{~m}^{3}$ concrete of beams for all models is shown in Fig. 2. The steel tonnage is normalised to the nonseismic model for comparison to the current practice which not considering seismic design. In Fig. 2, the steel tonnage used as reinforcement in beam increases when the seismic design has been taken into account. Regardless the soil type, the steel tonnage increased around $14 \%$ to $119 \%$. The increment is higher for models considering higher value of reference peak ground acceleration, $\alpha_{\mathrm{gR}}$. This result mean regions with higher level of seismicity tend to demanding higher cost of steel reinforcement for beam. Previous study [11] also presented similar pattern. The soil type also influencing the increment of steel tonnage. For a similar level of seismicity, models considering soil type $\mathrm{E}$ have the highest steel tonnage. As discussed in previous subsection, model E- $0.10 \mathrm{~g}$ has the highest magnitude of base shear force, $F_{\mathrm{b}}$ result in highest lateral load acting on every storey. Based on structural analysis, the highest lateral force contributed to the highest magnitude of the bending moment, $M$ as well as the shear force, $V$ which result in highest amount of steel to be provided as reinforcement.

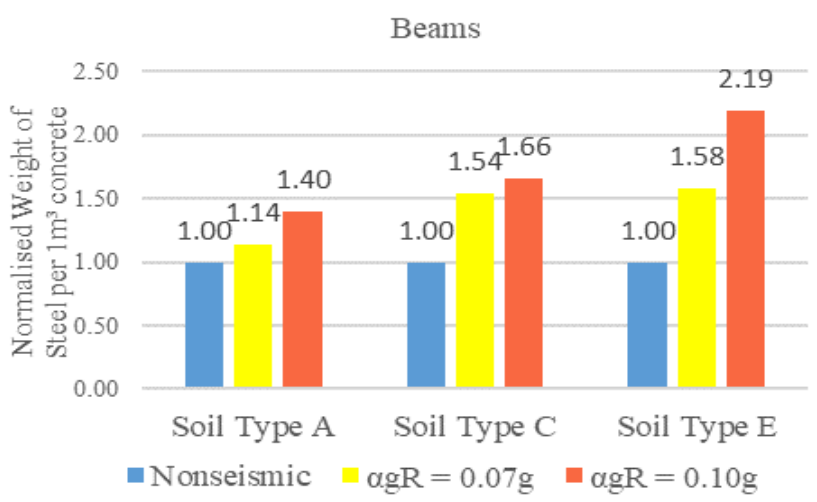

Fig. 2.Total steel tonnage for all beams

Column plays important role for stability of structural system. During earthquake events, the columns will vibrate back and forth. The torsional effect tends to caused heavier damage on columns [18]. Therefore, special attention has to be given for column design in order to resist the earthquake load. By referring to [13] the seismic design approach must include the Strong Column - Weak Beam philosophy which means that columns shall be stronger than beams. Fig. 3 shows the steel tonnage in $1 \mathrm{~m}^{3}$ concrete of columns for all models. The result shows similar pattern to the increment of steel tonnage in beams. In Fig. 3, the steel tonnage in columns for models with seismic design consideration increases around $13 \%$ to $155 \%$ higher compared to the control model without seismic design. This pattern is strongly influenced by the requirement of Strong Column - Weak Beam philosophy as mentioned before. Through this approach, the strength of column shall be at least 1.3 times the strength of its beam. Hence, the result directly follow the pattern for beam where the steel tonnage increases proportionately to level of seismicity. The results from this study is in good agreement compared to previous study [12].

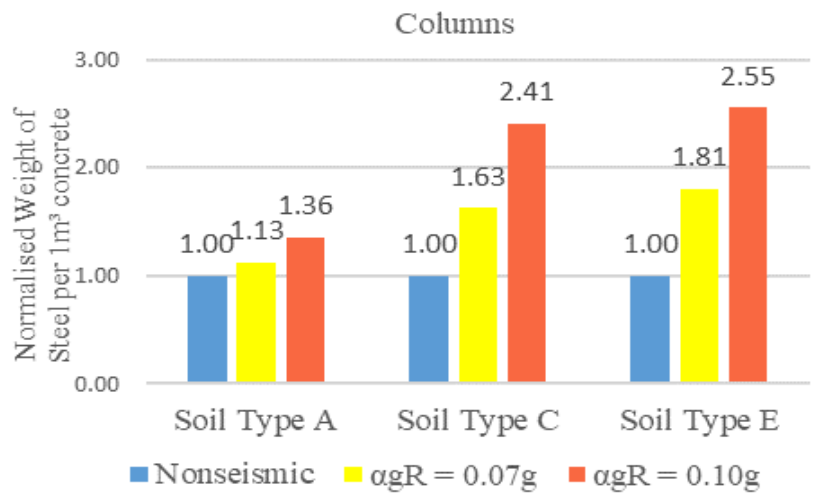

Total steel tonnage for all columns 


\section{Cost Estimation for Steel Reinforcement}

The art of $\mathrm{RC}$ design requires structural engineers to smartly selecting the size of section, as well as the number and size of steel bar for its reinforcement. Larger size of section will reduce the number as well as the size of steel bar, vice versa. The structural engineers also has to follow the minimum and maximum percentage of area of steel reinforcement per area of concrete section. For a typical building like school, standard size of section are preferred in order to maintain the aesthetic value of the building. Hence, the amount of steel reinforcement will be differ for every seismic level. Therefore, it is interesting to investigate the influence of seismic design on steel tonnage because it will determine the cost of material for beams and columns. The result will be useful for future development planning. The normalised total cost of steel reinforcement for beams and columns of all models is shown in Fig. 4. As referring to the results obtained for beams and columns, the cost of steel reinforcement increases by implementation of seismic design. For models on soil type A, the cost of steel reinforcement increases up to $38 \%$. The cost increment lies in range of $57 \%$ to $92 \%$ and $66 \%$ to $131 \%$ for models on soil type C and soil type E, respectively.

Generally, the cost for steel reinforcement increases around $13 \%$ to $131 \%$ depend on the level of seismicity and soil type. As discussed in previous subsection, both parameters strongly influencing the magnitude of base shear force, $F_{\mathrm{b}}$. The increase of base shear force, $F_{\mathrm{b}}$ tends to increase the magnitude of bending moment, $M$ which also directly increases the area of steel required, $A s_{\text {req }}$. As solution, the structural engineers has to use combination of larger size and/or higher number of steel bar in order to increase the area of steel provided, $A s_{\text {prov }}$. This means higher steel tonnage has to be used as reinforcement. Result from this study indicates that the level of seismicity and soil type strongly influencing the cost of steel reinforcement. Therefore, proper selection of site for development is important in order to reduce the cost of steel reinforcement.

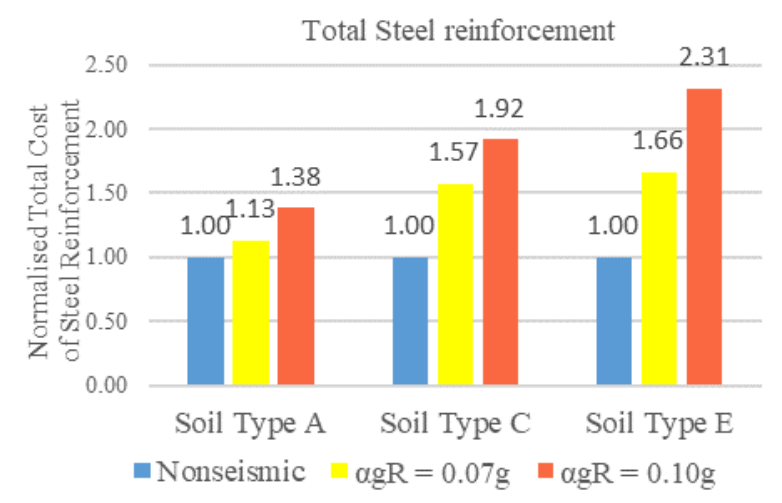

Fig. 3. Normalized cost of steel reinforcement

\section{CONCLUSION}

The increment of steel tonnage due to seismic design consideration has been investigated in this study. For that purpose, a four storey RC school building was generated and used as basic model. Two variables namely as level of seismicity and soil type has been considered for seismic design with ductility class medium. The level of seismicity was differentiated by the value of reference peak ground acceleration, $\alpha_{\mathrm{gR}}$ which lies in range of $0.04 \mathrm{~g}$ to $0.10 \mathrm{~g}$. Three types of soil namely as soil type A, soil type C, and soil type E has been taken into account to represent variability of site condition in Malaysia. A few conclusions are drawn as follow:

- The steel tonnage increases as the level of seismicity increases regardless the soil type. For beams, the increment is in range from $14 \%$ to $119 \%$ higher compared to nonseismic design. For columns, the increment is in range from $13 \%$ to $155 \%$.

- The site condition which is represented by soil type also influencing the increment of steel tonnage. Models considering softer soil profile require higher increment of steel tonnage compared to models which considering harder soil profile.

- By considering seismic design, total cost of steel reinforcement for beams and columns tend to increase around $13 \%$ to $131 \%$ depend on level of seismicity and soil type.

Current research works is improved by ongoing analysis and design considering various number of storey, function of buildings, soil type, level of seismicity, and concrete grade.

\section{ACKNOWLEDGMENT}

All authors acknowledged the financial support from Internal Research Grant number RDU1703240 (June 2017 June 2019) provided by Universiti Malaysia Pahang as well as facilities provided in design laboratory. Special thanks is dedicated to Azlina Nordin, Ummu Nurulatiqah Kamis, Anis Farhana Mazlan, Nur Hazwani Mohd Rashid, and Nur Izzati Aliah Azman for their effort as research assistants.

\section{REFERENCES}

1. A. Marto, C. S. Tan, F. Kassim, and N. Z. Mohd Yunus, "Seismic impact in Peninsular Malaysia," The 5th International Geotechnical Symposium, 2013, pp. 237-241.

2. J. Gill, N. S. Shariff, K. Omar, and Z. M. Amin, "Techtonic motion of Malaysia: analysis from years 2001 to 2013," ISPRS Annals of the Photogrammetry, Remote Sensing and Spatial Information Sciences, 2/W2, 2015, pp. 199 - 206.

3. A. H. Abdul Latiff and Khalil Amin Esmail, "Seismic site effect along Bukit Tinggi fault line from microtremor analysis," IOP Conference Series: Earth and Environmental Sciences, vol. 244, 2019, pp. 012042.

4. N. S. H. Harith, A. Adnan, F. Tongkul, A. V. Shoushtari, "Analysis on earthquake databases of Sabah region and its application for seismic design," International Journal of Civil Engineering \& Geo-Environmental, Special Publication NCWE2017, 2017, pp. 1-5.

5. T. A. Majid, A. Adnan, M. I. Adiyanto, M. Z. Ramli, T. C. Ghuan, "Preliminary damage assessment due to 2015 Ranau earthquake," International Journal of Civil Engineering \& Geo-Environmental, Special Publication NCWE2017, 2017, pp. 49-54.

6. S. C. Alih and M. Vafaei, "Performance of reinforced concrete buildings and wooden structures during the $2015 \mathrm{M}_{\mathrm{w}}$ 6.0 Sabah earthquake in Malaysia," Engineering Failure Analysis, vol. 102, 2019, pp. 351-368

7. M. I. Adiyanto, T. A. Majid, F. M. Nazri, "Nonstructural damages of reinforced concrete buildings due to 2015 Ranau earthquake," AIP Conference Proceedings, vol. 1865, 2017, pp. 090002. 
8. M. A. Khoiry, N. Hamzah, S. A. Osman, A. A. Mutalib, R. Hamid, "Physical damages effect on residential houses caused by the earthquake at Ranau, Sabah Malaysia," International Journal of Engineering and Technology, vol 10(5), 2018, pp. 414-418.

9. N. H. Hamid, A. Azmi, M. I. Adiyanto, M. Mohamad, "Seismic performance of two-bay two-storey rc frame under in-plane lateral cyclic loading," Malaysian Construction Research Journal, vol 25(2), 2018, pp. 61-73.

10. M. I. Adiyanto and T. A. Majid, "Seismic design of two storey reinforced concrete building in Malaysia with low class ductility," Journal of Engineering Science and Technology, vol 9(1), 2014, pp. 27-46

11. M. Z. Ramli, A. Adnan, M. A. A. Kadir, and M. N. A. Alel, "Cost comparison for non-seismic (EC@) and seismic (EC8) design in different ductility class," International Journal of Civil Engineering \& Geo-Environmental, Special Publication NCWE2017, 2017, pp. 38-42.

12. M. I. Adiyanto, F. Ahmad Jani, S. A. H. S. Mustapha, and S. W. Ahmad, "Estimation on amount of steel reinforcement for six storey hospital with seismic design consideration in Malaysia," IOP Conference Series: Earth and Environmental Sciences, vol. 244, 2019, pp. 012015.

13. CEN., "Eurocode 8: design of structures for earthquake resistance part 1: general rules, seismic actions and rules for buildings," European Committee for Standardization, Brussels, Belgium, 2004.

14. M. N. Fardis, E. C. Carvalho, P. Fajfar, and A. Pecker, Seismic design of concrete buildings to Eurocode 8. Boca Raton, Taylor \& Francis, 2015, ch. 1 .

15. CEN., "Eurocode 1: Action on structures part 1: general actions densities, self weight, imposed loads for buildings," European Committee for Standardization, Brussels, Belgium, 2002.

16. Malaysia National Annex to Eurocode 8, "Design of structures for earthquake resistance part 1: general rules, seismic actions and rules for buildings," Department of Standards Malaysia, Selangor, Malaysia, 2017.

17. A. Y. Elghazouli, Seismic design of buildings to Eurocode 8. London and New York, Spon Press, 2009.

18. S. M. Noor, N. S. Md Halim, A. Ibrahim, T. A. Majid, and S. H. Hassan, "Fundamental period of vibrations influencing characteristics of torsional irregularity in reinforced concrete buildings," IOP Conference Series: Earth and Environmental Sciences, vol. 244, 2019, pp. 012021.

\section{AUTHORS PROFILE}

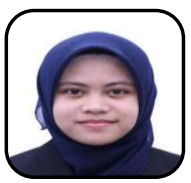

Hanis Athirah Roslan is a postgraduate student at Department of Civil Engineering, College of Engineering, Universiti Malaysia Pahang. Her research focused on earthquake engineering and seismic design.

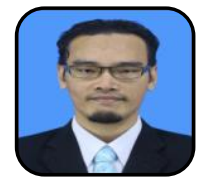

Mohd Irwan Adiyanto is a senior lecturer at Department of Civil Engineering, College of Engineering, Universiti Malaysia Pahang. His research focused on earthquake engineering and seismic design.

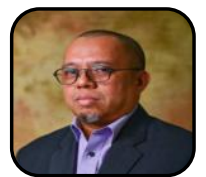

Syed Abdul Haris Syed Mustapa is a senior lecturer at Department of Quantity Surveying, Faculty of Architecture, Planning, and Surveying, Universiti Teknologi Mara. His research focused on quantity taking off and costing

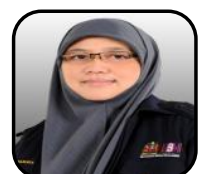

Taksiah A Majid is a Professor at School of Civil Engineering, Universiti Sains Malaysia. Her research focused on earthquake and wind engineering.

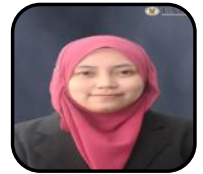

Noor Sheena Herayani Harith is a senior lecturer Faculty of Engineering, Universiti Malaysia Sabah. Her research focused on earthquake structures and engineering seismology 